\title{
Developing the Underwriting Process in Life Insurance
}

\author{
Yuldashev Obiddin Toshmurzaevich
}

\begin{abstract}
Underwriting is the main factor affecting the reliability, stability of the organizational development of the life insurer and determining the quality of financial management, strategic planning, budget management of the life insurer, the economic feasibility of the life insurance process, the adequacy of the life insurer's operational management system. Underwriting is the main business process in insurance organizations and provides for the assessment and management of insurance risk accepted for insurance. This study focuses on the economic nature of underwriting, the approaches of scientists to it, the specifics of life insurance underwriting, types of life insurance underwriting and the process of their implementation, as well as directions and stages of underwriting in life insurance. The article also substantiates that digitalization of the underwriting process in life insurance is an important factor in its development. In concluding life insurance contracts, regardless of the type of insurance product, according to the author, underwriting should be carried out gradually in several directions.
\end{abstract}

Index Terms - underwriting, insurance portfolio, business process of life insurance, standard and individual underwriting.

\section{INTRODUCTION}

In modern conditions, the role of life insurance in ensuring the safety of human life activities is constantly growing. At the same time, life insurance becomes not only a necessity for the development of the insurance market, but also a particularly attractive business. However, success in this business cannot be achieved without studying the theory and practice of life insurance, its technological features, and special professional knowledge.

One of the main business processes of life insurance is underwriting is to accept. Underwriting is a key link in the system of insurance relations at all stages of the development of insurance business because the successful conduct of insurance operations and the benefit of the insurer depends on its effective organization.

In short, underwriting is the activity of the insurer aimed at assessing the risks accepted for insurance, determining the appropriate tariff rate and insurance conditions, the formation of a profitable insurance portfolio. In order to carry out this activity effectively, highly qualified specialists (underwriters) who can solve the complex problems of assessing the objects of insurance and determining the probability of occurrence of risks are required.

In the process of underwriting, the procedure for concluding an insurance contract is determined in advance,

Published on December 30, 2020.

Yuldashev Obiddin Toshmurzaevich, Banking and Finance academy of the Republic of Uzbekistan, Uzbekistan.

(e-mail: obiddinyuldashev@gmail.com) as the insurance company assumes liability for possible material losses of the insured in exchange for a certain fee (insurance premium). Therefore, the underwriter is responsible for properly assessing the risks offered for insurance and making a final decision on the terms, terms, etc. of insurance. For its successful implementation, the underwriter must address the following issues related to the assessment of risks of potential policyholders:

- Should the risk be insured or not?

- Is there any reason to suspect the client of dishonesty (fraud)?

- What risk group should be included in the proposed risk for insurance?

- Under what conditions should the risk be insured?

\section{LITERATURE REVIEW}

In some scientific literature, underwriting is mainly considered as a business process related to the assessment of insurance risks of the insurance company, development of specific terms of the insurance contract and determination of optimal insurance tariffs [1]-[3]. In others, the description of underwriting focuses on issues such as the specifics of its organization, functions, stages of implementation, the implementation of underwriting policy by type of insurance [4]-[6].

In general, there are different approaches to the interpretation of the term "underwriting", including not only as a business process of the insurance company, but also as a separate service for risk assessment, as a mechanism for managing the insurance portfolio, as a professional activity of the underwriter, as an object of accounting [7]-[9].

According to Gruzdova [10], underwriting in life insurance is the process of studying the initial data from the application of the insured, as well as additional information from the application documents and the results of the examination.

Kuznetsova [5] points out that, from the insurer's point of view, underwriting is a system of knowledge about risk management, the quality and professionalism of which depends on the choice of the insurer.

Underwriting is one of the most important factors influencing the quality of an insurer's budget management, strategic planning, and financial management, as well as its sustainable development and reliability, Vlasov [7] said.

In addition, Arkhipov's [1] work on insurance underwriting reflects the essence of underwriting, risk management in life insurance, actuarial calculations, tariff policy, underwriting methodology, modern trends in underwriting in life insurance. So, A. P. Arkhipov notes: "Underwriting is a business process in insurance, which consists in accepting for insurance (reinsurance) or rejecting the declared object of insurance based on an assessment of 
the individual risks inherent in the object in order to form or amend the terms of the insurance contract and determine the insurance rate" [1].

According to Nikulina and Yasenev [2], the concept of underwriting at the present stage of development of the insurance market is changing dramatically and, accordingly, its role in insurance business is changing. Underwriting is the basis for making management decisions about the possibility of insuring potential risks.

Underwriting in life insurance is, in our opinion, a set of measures aimed at determining the limits of acceptance of risks in order to ensure that insurance services are provided on a contractual basis that satisfies the insurer and the insured, as well as protects the insurance portfolio (types of insurance or insurance products) and agree or set the terms of the insurance contract (content of risks accepted for insurance, insurance rates, the size of the deductible).

\section{METHODS}

The study used scientific abstraction, grouping, comparison, retrospective and prospective, empirical analysis, and other methods. Using the method of scientific abstraction, the importance and necessity of life insurance underwriting in ensuring the balance and profitability of the insurance portfolio was substantiated, the scientific and practical importance of ensuring the financial stability of insurance operations was predicted. Also, through the method of comparative comparison, the relevant conclusions were formed by comparing the financial and organizational basis of the underwriting policy used in the world insurance practice and in developed countries with the existing basis in our country. Indicators of standard criteria of life insurance risks were developed.

\section{RESULTS AND DISCUSSION}

In general, we believe that an insurance company should pursue an optimal underwriting policy, because too much rigor in assessing risks and determining the terms of their insurance hinders the sale of insurance products, and conversely, a superficial approach to this issue affects the company's financial stability. This means that the financial stability of an insurance company depends in many ways on the professionalism of the underwriter, while the underwriting process is different for each type of insurance.

When concluding life insurance contracts, regardless of the type of insurance product, in our opinion, underwriting should be carried out step by step in the following areas:

1) Medical underwriting is a medical assessment of the health status of a potential insured (or the insured person). On the basis of various medical data collected, the health of the insured person is assessed, the presence of certain diseases or susceptibility to uninsured diseases is determined, the appropriate tariff rate is set for him (or insurance is denied). The information studied in this process includes the following:

- answers to the questions of the insured person in the application (personal data, including age, sex, permanent residence; working and leisure conditions, factors leading to early death; bad habits; list of diseases and current state of health in the last few years);

- information in the questionnaire attached to the application (health status: height, weight, blood pressure, bad habits, registration in a dispensary; the presence of certain diseases in himself or close relatives; previous life insurance contract; occupation, sports, tourism, travel, dependence of life activities on high risks; source of income);

- report of the doctor who treated him;

- the results of the medical examination;

- the results of special medical examinations.

2) Professional underwriting, which assesses the dependence of the professional activity of a potential insured (or the insured person) on a high level of risk. His profession, experience, qualifications, working conditions, amenities, environment (occurrence of an accident or natural disaster), and business trips are explored.

3) Lifestyle underwriting - living conditions, housing, nature, marital status (single, elderly, married), dangerous sports, lifestyle risks or the risk of contracting infectious diseases (including AIDS) as a result of entertainment.

4) Financial underwriting is an assessment of the financial condition of a potential insured. Financial underwriting is done to make sure that the life insurance policy (especially the sum insured and the insurance premium) provided to the potential insured meets the solvency and financial needs of that person. Such an assessment allows to determine the real income of the insured and reduce the risk of non-sale of insurance policies.

5) Criminal underwriting - assesses the risks associated with the unconditional connection of the potential insured with the criminal world, the propensity to commit fraud or fraudulent insurance, the legitimacy of their income.

The most important aspect of the underwriting process in life insurance is that it involves the simultaneous assessment of the level of risk in all of the above areas and is carried out comprehensively. However, in our opinion, the most important stage of risk assessment is medical underwriting, because if the health of the potential insured is unsatisfactory, the next stages of the underwriting process will not be relevant.

Underwriting in life insurance is based on the study of the primary data in the application and application of the potential insured (standard underwriting) or the study with the addition of additional information and examination results (individual underwriting).

Standard underwriting includes the analysis of the insurance application and the attached application form, as well as the determination of compliance of the information provided by the potential insured with the standard criteria. If the data fully meet the indicators of the standard criteria of risks, the application for insurance is recognized as standard (Table I) and the contract is concluded on the basis of standard underwriting conditions. Insurance companies independently determine the indicators of the standard criteria of risks, in our opinion, in this process should take into account the conditions of reinsurance, the expected financial results on the types of insurance activities and other indicators. 
TABLE I: STANDARD CRITERIA FOR RISKS IN LIFE INSURANCE INDICATORS

Standard

criteria

General

physical

indicators

Professional

activity

Health status

The amount of

the sum insured

Source

income
Criteria indicators

- weight and height of the insured comply with the norm: if the weight is equal to $100-105$ minus from the height, it is considered normal (deviation that does not affect the assessment: plus-minus 15-20), the weight of an adult should not be less than $45-50 \mathrm{~kg}$; - blood pressure is normal (from 90/60 to 140/90); - consumes tobacco and alcohol in moderation.

The potential insured's professional activity is not associated with a high level of risk (military serviceman, rescue worker, special services, oil and nuclear industry worker, collector, explosives worker, underground, underwater, tunnel and mine worker, etc.), job not located in the "hot spot" or in the disaster zone, not on frequent and uninterrupted business trips

The potential insured has not suffered from any of the listed diseases (previously and now) specified by the insurer, no surgery has been performed on them

The insured is not interested in dangerous or risky sports (parachuting, long-distance swimming, snowboarding, motorsport, etc.)

The sum insured corresponds to the liability limit set in the underwriting policy (does not exceed)

of Legitimacy and solvency of the potential insured's income, its unquestionable connection with the criminal world

If all the information provided by the potential insurer does not meet the above criteria, the application is sent for individual underwriting.

In individual underwriting, the insurer's representative collects all the information necessary to determine the level of risk and submits it to a professional underwriter for review. In turn, the underwriter conducts a comprehensive risk assessment through questionnaires that include more detailed questions. If necessary, it requires additional documents (certificate from medical institutions, extract from the hospital card, certificate of employment, certificate of income, etc.), as well as an appropriate medical examination, and decides on what terms the insurance contract.

Underwriting is a risk analysis process; acceptance of risks for insurance (reinsurance) or rejection, including their assessment, classification into insurance or non-insurance, determination of the terms, conditions and amounts of coverage, calculation of premiums.

According to the point of view of the insured, underwriting is a system of knowledge on risk management, the quality and professionalism of possession of which depends on his choice of one or another insurer.

From the insurer's point of view, underwriting is the quintessence of insurance. High-quality underwriting entails a well-formed insurance and reinsurance portfolio, which are closest to the predicted loss ratio, and the calculated and applied insurance rates are justified. Quality underwriting for an insurer has two aspects: theoretical and practical.

The theory of underwriting is presented as a business process, which is formalized and described in the regulation on the underwriting center, job descriptions of underwriters, scenarios for underwriting, an expert system that supports management decisions regarding insurance and reinsurance.
The practical aspect is related to the high professionalism and competence of the underwriter as the most significant specialist-insurer, his skills, and abilities to process and analyze information regarding the risks of the object, transforming information into knowledge that can be applied in practice, that is, convenient for determining alternatives to insure or not, and if so, on what conditions.

Another important aspect of the underwriting process in life insurance is that it should be taken into account that the contract may expire in the first year of validity when a large sum insured is applied. That is, the insurer assumes certain costs when concluding each new insurance contract: administrative, underwriting costs, the formation of insurance reserves for future liabilities, and so on. These costs may be fully or partially covered by the insurance premium paid for the first year. However, if the contract expires in the first year of its validity, the insurer cannot cover its obligations with the insurance premiums received. Therefore, the underwriter must study each factor in detail and reject it when there is a possibility of death in the first year of the contract. If all the information provided by the potential insurer does not meet the above criteria, the application is sent for individual underwriting.

It is known that the balance and profitability of the portfolio of life insurance contracts is ensured through underwriting. The insurance portfolio reflects the basis on which the entire activity of life insurance companies is based, which determines the financial stability of insurance operations and the insurance company in general. Accordingly, the quality, structure and dynamics of the insurance portfolio depend on the amount of insurance premiums and insurance coverage paid to the company, the profitability of insurance and investment operations. According to this approach, the analysis of key indicators in the life insurance network is presented in Table II.

TABLE II: ANALYSIS OF KEY INDICATORS IN THE LIFE INSURANCE NETWORK OF UZBEKISTAN

\begin{tabular}{|c|c|c|c|c|c|}
\hline Indicators & 2015 & 2016 & 2017 & 2018 & 2019 \\
\hline $\begin{array}{l}\text { Life insurance premiums, } \\
\text { bln. sum }\end{array}$ & 33,3 & 59,1 & 138,6 & 417,2 & 586,4 \\
\hline $\begin{array}{l}\text { Growth compared to last } \\
\text { year, \% }\end{array}$ & 154,9 & 188,1 & 235,4 & 300,9 & 140,6 \\
\hline $\begin{array}{l}\text { Life insurance coverage, bln. } \\
\text { sum }\end{array}$ & 21,9 & 34,7 & 78,3 & 264,0 & 529,4 \\
\hline $\begin{array}{l}\text { Growth compared to last } \\
\text { year, } \%\end{array}$ & 196,4 & 167,3 & 264,1 & 337,1 & 200,6 \\
\hline $\begin{array}{l}\text { Number of life insurance } \\
\text { companies }\end{array}$ & 3 & 3 & 4 & 6 & 8 \\
\hline $\begin{array}{l}\text { The share of life insurance } \\
\text { premiums in GDP, } \%\end{array}$ & 0,017 & 0,025 & 0,047 & 0,10 & 0,12 \\
\hline $\begin{array}{l}\text { Life insurance premiums } \\
\text { relative to total insurance } \\
\text { premiums, } \%\end{array}$ & 6,0 & 8,5 & 14,9 & 25,5 & 25,3 \\
\hline $\begin{array}{l}\text { The share of insurance } \\
\text { coverage in relation to life } \\
\text { insurance premiums, } \%\end{array}$ & 65,8 & 58,7 & 56,5 & 63,3 & 90,3 \\
\hline
\end{tabular}

Based on the analysis of Table II, our conclusions are that the number of life insurance companies has increased in recent years, resulting in an increase in life insurance premiums, its share in GDP from $0.02 \%$ to $0.1 \%$, and its share in total insurance premiums from $6 \%$ to $25 \%$. Increased to 3 percent. 
At the same time, the determination of the share of insurance coverage of life insurance companies in relation to insurance premiums represents the result of the underwriting policy implemented.

TABLE III: THE SHARE OF INSURANCE COVERAGE IN RELATION TO INSURANCE PREMIUMS BY INSURANCE COMPANIES IN THE LIFE INSURANCE NETWORK, \%

\begin{tabular}{|c|c|c|c|c|c|c|}
\hline № & Insurance companies & 2015 & 2016 & 2017 & 2018 & 2019 \\
\hline 1. & $\begin{array}{l}\text { "Uzbekinvest Hayot" } \\
\text { LLC }\end{array}$ & 66,7 & 56,4 & 59,2 & 67,3 & 116,1 \\
\hline 2. & "Alfa Life" IC & 66,7 & 46,4 & 70,9 & 72,1 & 58,0 \\
\hline 3. & $\begin{array}{l}\text { "New Life Insurance" } \\
\text { LLC }\end{array}$ & 62,0 & 68,1 & 55,9 & 61,7 & 107,6 \\
\hline 4. & "Agros Hayot" LLC & - & - & 25,6 & 61,0 & 114,0 \\
\hline 5. & "Euroasia Life" LLC & - & - & - & 20,0 & 30,4 \\
\hline 6. & "Kafolat Hayot" LLC & - & - & - & 10,0 & 64,3 \\
\hline 7. & "Apex Life" LLC & - & - & - & - & 8,0 \\
\hline 8. & "Alskom Vita" LLC & - & - & - & - & 16,7 \\
\hline & Total & 65,6 & 58,4 & 56,5 & 63,2 & 90,3 \\
\hline
\end{tabular}

The data in Table III show that the volume of insurance coverage paid by life insurance companies, including its share in insurance premiums, increased sharply in 2019. This is evidenced by the fact that in the last two years in our country, long-term life insurance, including savings life insurance, has expanded, and the number of contracts has increased. The share of insurance coverage in insurance premiums in some insurance companies, which expanded their activities on this insurance in 2019 , amounted to 107 $116 \%$ due to the full return of insurance premiums collected in long-term life insurance after the expiration of the contract and the payment of interest on it.

\section{CONCLUSION AND RECOMMENDATIONS}

In our opinion, there are the following problems in the development of underwriting activities in life insurance:

- One of the main problems of underwriting in life insurance is that the management of (usually small) insurance companies often entrust this important and complex task to ordinary insurance agents, although they do not have professional knowledge and skills in this regard. In addition, the salaries of insurance agents are not fixed, they are paid as a percentage of insurance premiums received under insurance contracts. This, in turn, leads to incorrect motivation of the insurance agent, who tries to conclude more insurance contracts without paying special attention to their quality. As a result, in the event of an insured event, the insurer will try to minimize or deny insurance payments as much as possible. In such circumstances, there can be no talk of developing underwriting.

- The current situation is exacerbated by the lack of qualified personnel in this field, all of whom are inexperienced or unskilled. The main reason for this problem is that at present in our country the specialty of insurance underwriter is not trained. Lack of information in Uzbek about underwriting activities not only in life insurance, but also in insurance in general, the lack of theoretical resources is the reason why the knowledge of specialists in this area is not well formed.

- The underwriter is a key employee of the insurance company, in contrast to the insurance agent, has a fixed salary. On the plus side, you are guaranteed to receive a certain amount of salary each month, there are fixed working days, holidays, and vacations. However, the underwriter cannot find "big bonuses" for himself, which does not encourage them to create a positive image of the insurance company, but rather tries to get rich quickly. All this creates signs of corruption in the insurance company.

- Insufficient methodological support of risk management and comprehensive assessment in life insurance is one of the main problems of the underwriting process. An effective way to solve this problem is to develop methods of risk assessment of life insurance on the basis of advanced foreign experience and the greatness of the underwriter's work. This, in turn, allows for the rapid formation of the insurance portfolio and its effective management.

- Implementation of life insurance reforms in the country, the entry of new life insurance companies into the market the strengthening of the competitive environment pose new challenges for underwriters, including maintaining customer base while competitors actively implement dumping policies, further improving the quality of insurance services and profitability of insurance business level.

- Underwriting is the main business process in insurance companies, which provides assessment and management of risks accepted for insurance. However, currently underwriting digital technologies in life insurance is the least used business process. In this regard, the effective use of digital technologies in the underwriting process is one of the priorities in the development of not only this business process, but also life insurance.

International experience of insurance practice shows that digital technologies allow faster and more accurate assessment of the risks of potential policyholders in the process of medical underwriting in life insurance on the basis of additional information obtained through special computer programs (websites, social networks). In particular, through the photos of the insured person's account on social networks, it is possible to obtain and analyze additional information about his lifestyle, habits, social status, interests, illness, in general, his health.

Digitization of the underwriting process in life insurance Accurate assessment of risks under the insurance contract, automation and electronic (online) programming of the old data collection procedure of the underwriter, including the involvement of artificial intelligence, individualization of insurance services by modeling consumer behavior of potential insured, allows to reduce [11].

The digitization of the underwriting process in life insurance and the introduction of modern computer software, in our opinion, will have a positive effect at all stages of underwriting, including:

- comfortable working conditions are created for employees;

- the processes of collection, use, analysis and exchange of information by specialists will be accelerated, simplified and costs will be reduced;

- there will be an effective way of exchanging information between the underwriting department and other divisions of the insurance company;

- data integrity and security are ensured at all stages of information processing;

- allows accurate assessment of insurance risks, setting 
optimal tariffs, timely payment of insurance coverage;

- it is possible to automate the formation of insurance reserves, their placement in high-yield investment facilities and the formation of the insurance portfolio;

- simplifies the rapid analysis of the activities of the heads of underwriting departments, the preparation of operational analytical reports for management and relevant higher organizations;

- the management of the insurance company will be able to quickly monitor the information describing the financial condition of the company, evaluate the underwriting activities and the insurance portfolio, as well as quickly determine the financial results for each type of insurance.

In general, the widespread introduction of digital technologies will pave the way for the provision of life insurance services that can meet world standards and enhance the reputation of the insurance company.

\section{REFERENCES}

[1] A. P. Arkhipov, Strahovoj anderrajting: uchebnik i praktikum dlya bakalavrov - 2-e izd., pererab. $i$ dop [Insurance underwriting: textbook and workshop for bachelors], Moscow: Publishing house Yurayt, 2016, p. 359.

[2] N. E. Nikulina, V. N. Yasenev, "Underwriting in insurance business," Ekonomicheskiy analiz: teoriya i praktika [Economic analysis: theory and practice], vol. 22, pp. 277, 2012.

[3] N. P. Nikolenko, "Underwriting is a key business process in an insurance company," Information and analytical portal "Insurance Today”, 2019, URL: http://www.insur-info.ru/comments.

[4] S. A. Burlyaev, "Underwriting in property types of insurance: role, functions, problems of organization and control," Uchenye zapiski Sankt-Peterburgskogo universiteta upravleniya $i$ ekonomiki [Scientific notes of the St. Petersburg University of Management and Economics], no. 3(43), pp. 32-38, 2013.

[5] T. E. Kuznetsova, "Underwriting system in modern conditions of the insurance market of Russia," Vestnik Volzhskogo universiteta im. V.N.Tatishcheva [Bulletin of the Volga University named after V.N.Tatishcheva], no. 2, pp. 55-60, 2016

[6] T. A. Pavlova, M. V. Kosyakova, Ya. O. Shalimov, "Underwriting procedure and its role in the economic security of insurance companies," Actual problems of social and humanitarian Sciences, Collection of scientific papers based on the materials of the International scientific and practical conference, 2017, pp. 92-99.

[7] P. A. Vlasov, "Insurance portfolio management in modern Russian conditions," Uchenye zapiski Sankt-Peterburgskogo universiteta upravleniya $i$ ekonomiki [Scientific notes of the Saint Petersburg University of management and Economics], no. 3(51), pp. 12-21, 2015 .

[8] T. N. Pavlyuchenko, "Insurance underwriting as an object of accounting," Aktual'nye voprosy ekonomicheskih nauk [Actual issues of economic Sciences], vol. 7. pp. 175-180, 2009.

[9] M. V. Shepeleva, "Improving the insurance portfolio management system using underwriting," Uchenye zapiski Rossiyskyj Akademii predprinimatel'stva [Scientific notes of the Russian Academy of entrepreneurship], no. 12. pp. 190-199, 2008.

[10] V. A. Gruzdova, "General approaches to risk assessment in personal insurance on the example of life insurance," Izvestiya Penzenskogo gosudarstvennogo pedagogicheskogo universiteta im. $\quad$ V. G. Belinskogo [News of the Penza State Pedagogical University named after V.G.Belinsky], no. 22, pp. 250-254, 2010.

[11] D. V. Bryzgalov, "Digitalization of underwriting in the Russian insurance market," Tsifrovaya ekonomika [Digital Economy], vol. 1. pp. 90-101, Jan. 2020.

[12] O. T. Yuldashev. (October 2020). Development prospects of investment insurance product "Unit-Linked". International Finance and Accounting, [Online] vol. 5. pp. 1-10. Available: https://www.interfinance.uz/en/.

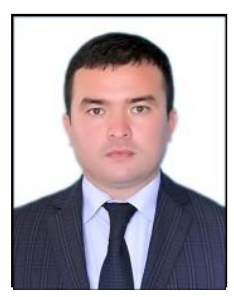

Yuldashev Obiddin Toshmurzaevich

Date of birth: 06.11.1983

Educational background: graduated in 2007 Tashkent

State University of Economics.

Academic degree: $\mathrm{PhD}$ in "Finance, money circulation and credit", Banking and Finance academy of the Republic of Uzbekistan, 2011.

Current job: senior researcher of Banking and Finance academy of the Republic of Uzbekistan. Current research interests: "Life insurance and fundamental issues of its development". 